\title{
Frequency of iodine deficiency disorders among children living in the iodine deficiency region
}

\author{
Tamila Sorokman, Marina Bachu, Iryna Sokolhyk
}

Department of Pediatrics and Medical Genetics, Bukovinian State Medical University, Chernivtsi, Ukraine

\begin{abstract}
Introduction. Currently, only a small number of countries have a stable iodine adequacy, about a third of the world's population lives in areas with some iodine deficiency. Because children have an increased risk of adverse effects in response to iodine deficiency, it is important to assess the health of these children.

Aim. To investigate the frequency of iodine deficiency in children from the iodine deficiency region.

Methods. The research was conducted during expeditions to various geographical areas of Northern Bukovyna (Chernivtsi region, Ukraine). 1,973 school-age children were examined (measurement of anthropometric indicators, assessment of cognitive, physical and sexual development, ultrasonography of the thyroid gland (TG), ovaries and testicles, determination of hormonal status and iodine in urine).

Results. Of 1,973 children, $53.7 \%$ (1060) had thyroid abnormalities. The frequency of goiter in the mountain zone $59.8 \%$. In $12.3 \%$ of children there was a tendency to increase of TSH. The median ioduria in children from mountainous areas corresponds to moderate iodine deficiency. Children from mountainous areas have various disorders: $38.5 \%$ disharmonious physical development, a third low intellectual development, disorders of the order of appearance and development of secondary sexual characteristics in the examined children.

Conclusion. The results of the study show the negative impact of iodine deficiency on the body of children. It is necessary to continue monitoring of ioduria and children's health and implement preventive measures.
\end{abstract}

Keywords: children, median ioduria, iodine deficiency disorders

\author{
Abbreviations \\ $\mathrm{TG}-$ thyroid gland \\ UNICEF - United Nations Children's Fund \\ WHO - World Health Organization \\ ICCIDD - International Committee for Control of Iodine \\ Deficiency Disorders \\ IDD - iodine deficiency diseases \\ UIC - urinary iodine concentration \\ $\mathrm{TSH}$ - thyroid-stimulating hormone
}

\author{
$\mathrm{HG}$ - health groups \\ MI - masculinization index \\ DD - disharmonious development \\ OBW - over body weight \\ DBW - deficit body weight \\ SSDB - score of sexual development of boys \\ SSDG - score of sexual development of girls
}

\section{INTRODUCTION}

Iodine deficiency (excretion of iodine in the urine less than $100 \mathrm{mcg}$ /day) causes serious adverse health effects and is a major cause of mental retardation that can be prevented in childhood [1]. Almost two billion people are at risk of developing iodine deficiency disease (IDD) [2]. And this is a global health problem [3]. Iodine deficiency is common in the world [4-7], especially in Asia [8-13], Africa [14], Eastern Europe [15-18]. Currently, only a small number of countries have stable iodine adequacy, about a third of the world's population lives in areas with some iodine deficiency, severe iodine deficiency is observed in mountainous areas such as the Alps, the Himalayas, the Carpathians [19]. Access to iodized salt is partial (Fig. 1). 


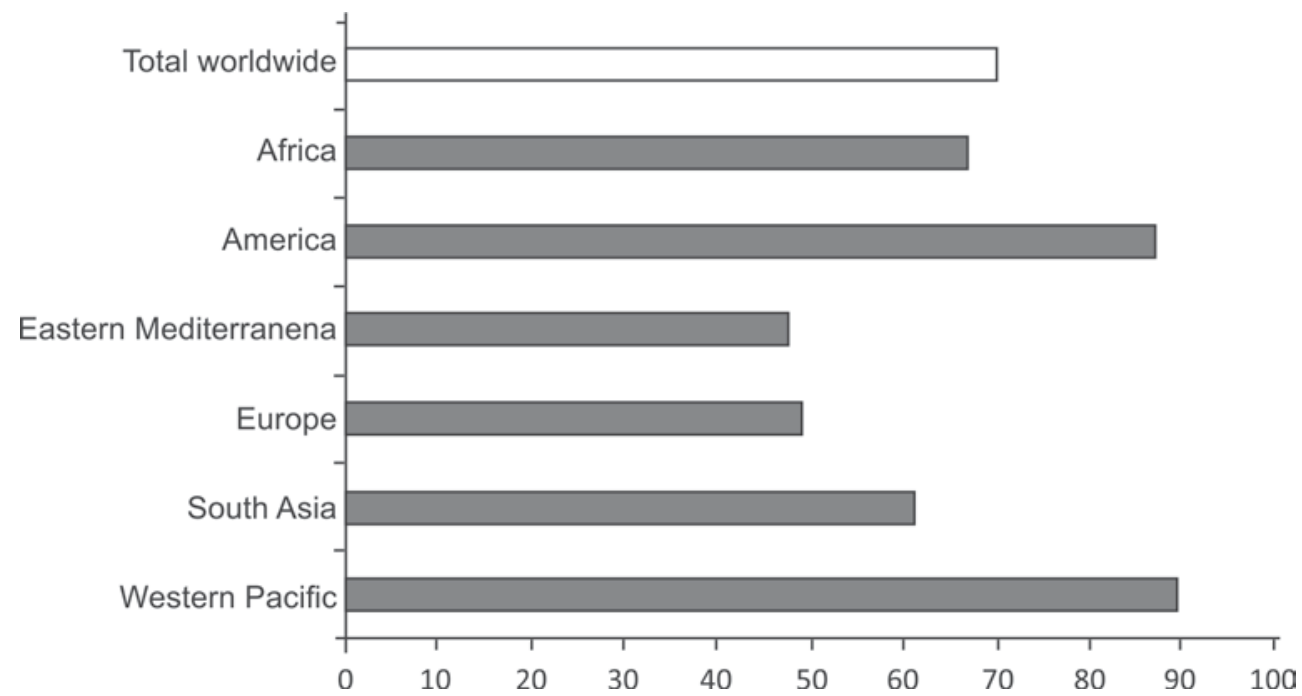

FIGURE 1. Proportion of households with access to iodised salt in various parts of the world; Adopted from UNICEF, 2007 [20]

In 1991, the world health assembly (WHA) declared iodine deficiency as a major public health problem which should be eliminated by the year 2000. This goal had been endorsed in 1990 by world leaders when they met at the United Nations world summit for children. The World Health Organization (WHO) and United Nations Children's Fund (UNICEF) recommended universal salt iodization (USI) for elimination of IDD in 1992 and 1993. Considerable progress has since been achieved, and it has been estimated that at least 75 million newborns entering the world in 2002 had been protected against the brain damage caused by iodine deficiency. In East Asia and Pacific, 20.8 million (16\%) of the global newborns and in South Asia 9 million, (14\%) were the highest numbers of newborns who were protected [20]. Data made available by WHO shows that $31.5 \%$ (264 million) of schoolchildren and $30.6 \%$ (2000 million) of the general population worldwide have insufficient iodine intake [21,22]. National $(n=121)$ or large subnational $(n=31)$ surveys were conducted in 152 countries, representing $98 \%$ of the world's population. In 2014, iodine consumption was sufficient in 112 countries, deficient in 29 countries and excessive in 11 countries. The number of iodine-sufficient countries has increased from 67 to 112 in recent years [23]. However, even economically developed countries have iodine deficiency [24]. Because children have an increased risk of adverse effects in response to iodine deficiency, it is important to assess the health of these children.

\section{AIM}

To investigate the frequency of iodine deficiency in children from the iodine deficiency region.

\section{METHODS}

The research was conducted during expeditions to various geographical areas of Northern Bukovyna (Chernivtsi region, Ukraine), which are divided into plains and mountains in terms of natural, climatic and socio-economic features. 1973 school-age children were examined. The examination program included: questionnaires, measurement of anthropometric indicators, assessment of cognitive, physical and sexual development, ultrasonography of the thyroid gland (TG), ovaries and testicles, determination of hormonal status and iodine in the urine. Criteria for inclusion in the study: age 7-18 years, living in the Chernivtsi region, absence of somatic pathology of the central nervous system. Criteria for exclusion from the study: conducting a contrast X-ray examination and the use of iodine-containing drugs and thyroid hormones for 6 months.

Anthropometric measurements were performed in the morning, 1.5-2 hours after breakfast with a standard stadium meter and medical scales. The result was rounded to the nearest $0.5 \mathrm{~cm}$ and $0.5 \mathrm{~kg}$. The obtained data of anthropometric measurement of children were evaluated according to regional standards [25].

The formation of intellectual function was determined using a fragment of theR. Kettel test (adapted modified version of the children's personality questionnaire R. Kettel) [26]. The sexual development of children was assessed by the severity of primary and secondary sexual characteristics, indicators of ultrasound examination of the internal genitals on the Scanner-100 using linear sensors with a frequency of 5 and $7.5 \mathrm{MHz}$. In order to mathematically reflect the sexual development of boys used the index of mascu- 
linization (MI) and the total score of sexual development of boys $(\mathrm{SSDB}=\mathrm{Ax}+\mathrm{P}+\mathrm{F}+\mathrm{L}+\mathrm{V})$, and girls calculated the score of sexual development of girls (SSDG) with the reflection of menstrual function $(\mathrm{SSDG}=\mathrm{P}+\mathrm{Ax}+\mathrm{Ma}+\mathrm{Me})[27]$.

Assessment of the thyroid gland (TG) was performed according to the indicators of visual-manual examination. According to the WHO classification [28], the degree of the TG is palpable, the particle size corresponds to the distal phalanges of the patient - I degree, the particle size exceeds the size of the patient's distal phalanges - II degree, the particle size exceeds the size of the distal phalanges - III.

Ultrasonographic examination of the TG was performed on a Scanner-100 using a linear sensor with a frequency of $7.5 \mathrm{mHz}$. According to the parameters obtained during the ultrasonography, the volume of each thyroid lobe was calculated according to the formula: maximum thickness $/ \mathrm{cm} / \mathrm{x}$ width $/ \mathrm{cm} / \mathrm{x}$ length $/ \mathrm{cm} / \mathrm{x} 0.478$ and compared with the recommended thyroid volumes obtained during the examination of children in iodine-supplied regions Europe, taking into account age, sex and body area [29].

The functional state of the pituitary-thyroid system was assessed by clinical symptoms using screening integrated tables, as well as standard kits for RIA $\mathrm{T}_{3-}$ RIO-T 3 -PG, $\mathrm{T}_{4-}$ RIO-T $\mathrm{T}_{4}-\mathrm{PG}$, (Belarus), standard test kits from Mallinchbrodt (Germany) minus the $\mathrm{TSH} / \mathrm{T}_{4}$ index determined the concentration of thyroid-stimulating hormone (TSH).

Taking into account that the concentration of iodine in a single portion of urine correlates well with the level of iodine in daily urine, we took urine from children in test tubes by $5 \mathrm{ml}$ of urine at a time. The concentration of iodine was determined by ceriumarsenite method with preliminary wet ashing of its samples. According to the obtained data, the median ioduria was calculated, which was expressed in $\mu \mathrm{g}$ of iodine per 1 liter of urine.

The analysis of the data was carried out with the help of the software security of SPSS version 16 . The links between the fallow and non-fallen ones were seen. P-value $\leq 0.05$ was considered significant.

The study follows ethical principles for people who act as subjects of research, taking into account the main provisions of the GCR ICH and the Helsinki Declaration of the World Medical Association for Biomedical Research, where the person acts as their object (World Medical Association Declaration of Helsinki 1964, 2000, 2008), Council of Europe Convention on Human Rights and Biomedicine (2007) on the positive conclusion of the Commission on Bioethics of the Bukovinian State Medical University (protocol No. 5; 16.04.2017) and the local commission on biomedical ethics at the «Chernivtsi Regional Children's Clinical Hospital» (protocol No.9; 18.05.2017). This included adherence to the informed consent concept, consideration of the benefits over harm of risk, the principle of confidentiality and respect for the child's personality as a non-self-protective person, and other ethical principles for the children under study.

\section{RESULTS}

Of 1973 children, 53.7\% (1060) had thyroid abnormalities (Table 1) and 56.3\% (867) had no abnormalities. Among thyroid diseases, goiter was most often registered $-96.3 \%$, including: grade I goiter $77.1 \%$, grade II goiter $-14.6 \%$, diffuse toxic goiter $-2.3 \%$, nodular goiter $-2.1 \%$. In different climatic zones, the frequency of goiter is different (Fig. 2).

TABLE 1. Frequency of TG diseases in children (\%)

\begin{tabular}{|l|c|c|c|}
\hline \multirow{2}{*}{ TGD } & \multicolumn{3}{|c|}{ Area } \\
\cline { 2 - 4 } & $\begin{array}{c}\text { Chernivtsi } \\
\mathbf{n = 3 5 3}\end{array}$ & $\begin{array}{c}\text { Mountain } \\
\text { area } \\
\mathbf{n}=\mathbf{3 3 9}\end{array}$ & $\begin{array}{c}\text { Plain } \\
\text { area } \\
\mathbf{n}=\mathbf{3 6 8}\end{array}$ \\
\hline Goiter I degree, \% & 82.1 & $69.1^{*}$ & 80.1 \\
\hline Goiter II degree, \% & 10.1 & $21.5^{*}$ & 12.5 \\
\hline Nodular goiter, \% & 1.4 & $3,8^{*}$ & 1.3 \\
\hline Autoimmune thyroiditis, \% & 4.2 & 3,2 & 3.5 \\
\hline DTG, \% & 2.2 & 2.3 & 2.4 \\
\hline
\end{tabular}

* - probably in terms of indicators in children of Chernivtsi and the plain zone, $p<0.05$. TG - thyroid gland; TGD - thyroid gland diseases; DTG - diffuse toxic goiter

In prepubertal children living in Chernivtsi and the plains, goiter is slightly more common in boys, while in children in mountainous areas there is no gender difference. In addition, in girls of puberty, re-

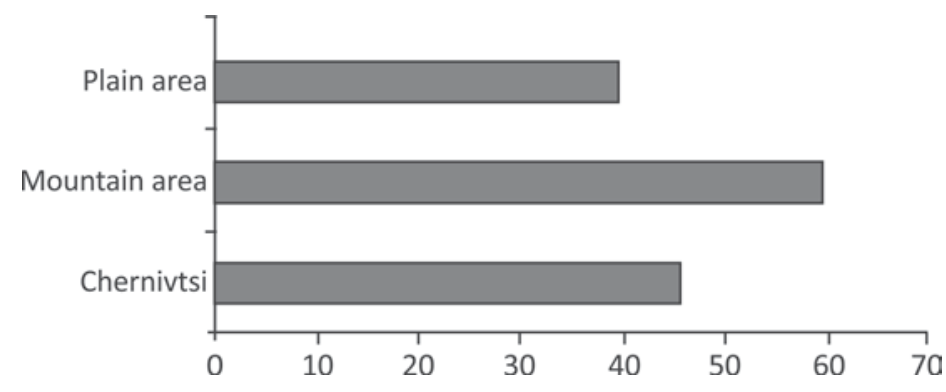

FIGURE 2. Frequency of goiter in children from different climatic zones (\%) 
gardless of place of residence, goiter is more common than in boys. The distribution of children with goiter in the mountainous area was noteworthy. Thus, in this population of children goiter of the II degree was more often registered $-21.5 \%$ against $10.1 \%$ in children of Chernivtsi $(\mathrm{p}<0.05)$.

In $89.3 \%$ of cases, diffusely enlarged, soft-elastic consistency, painless thyroid was detected, in $10.7 \%-$ the thyroid was slightly compacted. At ultrasound in $32.5 \%$ there was an increase in echogenicity, in $33.5 \%$ - a violation of the structure of the gland, in $24.3 \%$ a decrease in echogenicity. In 23 children (2.2\%) single nodes were found. The number of boys with ultrasonographic changes in the thyroid gland was $39.1 \%$, girls $-60.9 \%$. The results of the study of the functional state of the thyroid gland are shown in Table 2.

TABLE 2. The content of TSH and thyroid hormones in the peripheral blood of the examined children

\begin{tabular}{|l|c|c|}
\hline \multirow{2}{*}{ Indicators } & \multicolumn{2}{|c|}{ Gender } \\
\cline { 2 - 3 } & Boys $(\mathrm{M} \pm \mathrm{m}, \mathrm{n})$ & Girls $(\mathrm{M} \pm \mathrm{m}, \mathrm{n})$ \\
\hline $\mathrm{TSH}(\mu \mathrm{U} / \mathrm{l})$ & $2.23 \pm 0.27,48$ & $3.04 \pm 0.15,54$ \\
\hline $\mathrm{T}_{3}(\mathrm{nmol} / \mathrm{l})$ & $1.55 \pm 0.19,45$ & $1.71 \pm 0.16,54$ \\
\hline $\mathrm{T}_{4}(\mathrm{nmol} / \mathrm{l})$ & $89.04 \pm 8.73,45$ & $95,44 \pm 6.73,54$ \\
\hline $\mathrm{T}_{3} / \mathrm{T}_{4}$ & $0.013 \pm 0.003$ & $0.014 \pm 0.002$ \\
\hline $\mathrm{TSH} / \mathrm{T}_{4}$ & $0.023 \pm 0.004$ & $0.022 \pm 0.005$ \\
\hline
\end{tabular}

$12.3 \%$ of children were characterized by TSH in the range of age standards, which are shifted towards its increase (4.23-5.0 $\mu \mathrm{IU} / 1)$.

The results of determination of iodine in the urine of 399 children were characterized by a high amplitude of fluctuations $(17.7 \mu \mathrm{g} / \mathrm{l}-156 \mu \mathrm{g} / \mathrm{l})$ with average values of $55-70 \mu \mathrm{g} / \mathrm{l}$. The median ioduria in children from the plains and Chernivtsi was $67.54 \pm 4.02$ $\mu \mathrm{g} / 1$ and $69.32 \pm 3.99 \mu \mathrm{g} / \mathrm{l}$, which meets the WHO criteria for mild iodine deficiency and in children from mountainous areas $-29.34 \pm 3.11 \mu \mathrm{g} / \mathrm{l}$, which corresponds to the average degree of iodine deficiency.

When examining children without thyroid disorders, it was found that the first health groups (HG) include $11.6 \%$ of children, the second $-69.7 \%$, and the third $-18.5 \%$. The distribution of children by HG depending on the area of residence is given in Table 3.
TABLE 3. Distribution of children by HG depending on the area of residence (\%)

\begin{tabular}{|l|c|c|c|}
\hline HG & $\begin{array}{c}\text { Chernivtsi } \\
\mathbf{n = 4 2 0}\end{array}$ & $\begin{array}{c}\text { Mountain area } \\
\mathbf{n}=\mathbf{4 1 0}\end{array}$ & $\begin{array}{c}\text { Plain area } \\
\mathbf{n = 4 2 0}\end{array}$ \\
\hline 1 & 11.5 & $8.8^{*}$ & 12.3 \\
\hline 2 & 69.2 & 68.3 & 72.2 \\
\hline 3 & 19.3 & $22.9^{*}$ & 15.5 \\
\hline
\end{tabular}

HG - health groups; * - probably in relation to the indicators in children of Chernivtsi and the plain zone $(p<0.05)$

$15.5 \%$ of children with the third HG live in the plain zone, ie $7.4 \%$ less than in the mountain zone and $3.8 \%$ less than in Chernivtsi. The distribution of children by HG depending on age showed that with age the proportion of children of the third HG increases, especially at 13-14 years of age (table 4).

The group of frequently ill children was $11.2 \%$. The largest number of frequently ill children was observed in $13-14$ years $-32.3 \%$. SARS predominated among the transferred diseases, and among children living in mountainous areas, they were observed in $64.4 \%$, and among those living on the plains - in $42.5 \%$ of children. Respiratory diseases averaged $36.5 \%$ among the surveyed children, and they were more common in mountainous children. Digestive diseases occur in $14.2 \%$ of children. Diseases of the musculoskeletal system (kyphosis, scoliosis, flat feet, etc.) were observed in $18.0 \%$ of children. Posture disorders were more common after the age of $12.67 .3 \%$ of children have caries, and $20.6 \%$ are not treated.

The functional state of the thyroid in these children was not impaired: the average level of TSH 2.48 \pm 0.72 , T3 - $1.62 \pm 0.34,45 \mathrm{nmol} / \mathrm{l}, \mathrm{T} 4-92.14 \pm 8.3$ $\mathrm{nmol} / 1$.

The largest annual increase in length, body weight and chest circumference in children without thyroid changes is observed 1-2 years earlier than in children with goiter. At the age of 13-16 years, the average annual increase in body length in boys of both groups was greater than in girls. The results of physical development harmony analysis of children depending on gender and place of residence are shown in Table 5. Among children living in the plains and in Chernivtsi, the number of children with disharmonious physical development was lower and amounted to $30.77 \%$ and $23.86 \%$ in accordance.

TABLE 4. Distribution of children by HG depending on age (\%)

\begin{tabular}{|c|c|c|c|c|c|c|c|c|c|c|c|c|}
\hline \multirow[b]{2}{*}{$\mathrm{HG}$} & \multicolumn{12}{|c|}{ Age (years) } \\
\hline & $\begin{array}{c}7 \\
n=101\end{array}$ & $\begin{array}{c}8 \\
n=100\end{array}$ & $\begin{array}{c}9 \\
n=109\end{array}$ & $\begin{array}{c}10 \\
n=111\end{array}$ & $\begin{array}{c}11 \\
n=102\end{array}$ & $\begin{array}{c}12 \\
n=107\end{array}$ & $\begin{array}{c}13 \\
n=104\end{array}$ & $\begin{array}{c}14 \\
n=80\end{array}$ & $\begin{array}{c}15 \\
n=83\end{array}$ & $\begin{array}{c}16 \\
n=89\end{array}$ & $\begin{array}{c}17 \\
n=43\end{array}$ & $\begin{array}{c}18 \\
n=43\end{array}$ \\
\hline 1 & 13.7 & 12.5 & 11.0 & 13.8 & 14.0 & 11.2 & 6.4 & 7.7 & 10.2 & 15.9 & 14.2 & 12.2 \\
\hline 2 & 79.9 & 77.5 & 64.6 & 67.6 & 65.8 & 65.1 & 66.8 & 69.7 & 69.7 & 66.4 & 67.5 & 71.5 \\
\hline 3 & 6.3 & 9.9 & 15.5 & 21.4 & 18.2 & 22.8 & 28.3 & 25.3 & 19.9 & 17.5 & 18.3 & 16.3 \\
\hline
\end{tabular}

HG - health groups 
TABLE 5. Indicators of harmony of physical development of children depending on sex and area of residence (\%)

\begin{tabular}{|l|c|c|c|c|c|c|}
\hline \multirow{2}{*}{ Area } & \multicolumn{3}{|c|}{ Boys } & \multicolumn{2}{c|}{ Girls } \\
\cline { 2 - 7 } & $\begin{array}{c}\text { DD } \\
\text { (DBW) }\end{array}$ & HD & $\begin{array}{c}\text { DD } \\
\text { (OBW) }\end{array}$ & $\begin{array}{c}\text { DD } \\
\text { (DBW) }\end{array}$ & HD & $\begin{array}{c}\text { DD } \\
\text { (OBW) }\end{array}$ \\
\hline Chernivtsi & 9.29 & 79.29 & 11.42 & 11.79 & 73.00 & 15.21 \\
\hline Mountain area & 18.27 & $61.97^{*}$ & 19.76 & 18.75 & $60.99 *$ & 20.26 \\
\hline Plain area & 14.39 & 70.45 & 15.16 & 11.78 & 68.01 & 20.21 \\
\hline
\end{tabular}

* - probably in relation to the indicators of children in Chernivtsi and the plain area of residence; DD - disharmonious development; OBW-over body weight; DBW-deficit body weight

According to the analysis of the harmony of physical development among children living in the mountain zone, $38.52 \%$ have disharmonious physical development, and children with excess body weight and body weight deficit were equally common.

In children with goiter I-II degree from 14 years there is a clear tendency to lag behind in growth and at the age of 16 it is $8.25 \mathrm{~cm}(\mathrm{p}<0.05)$. We did not receive data that could be regarded as a "pubertal leap" in children with goiter. Children with goiter in all age groups had lower body weight compared to children without goiter, with boys of 12 and 13 years of age and girls of 13 years of age experiencing this difference. The dynamics of body weight in children with goiter is characterized by uneven growth in certain age groups, especially in boys and girls at 14 years of age. The number of children with goiter and body weight deficit compared to children without goiter is probably increased ( $\mathrm{p}<0.001)$.

In general, children with goiter have a probable ( $\mathrm{p}$ $<0.01)$ decrease in the proportion of children with harmonious physical development (Fig. 3).
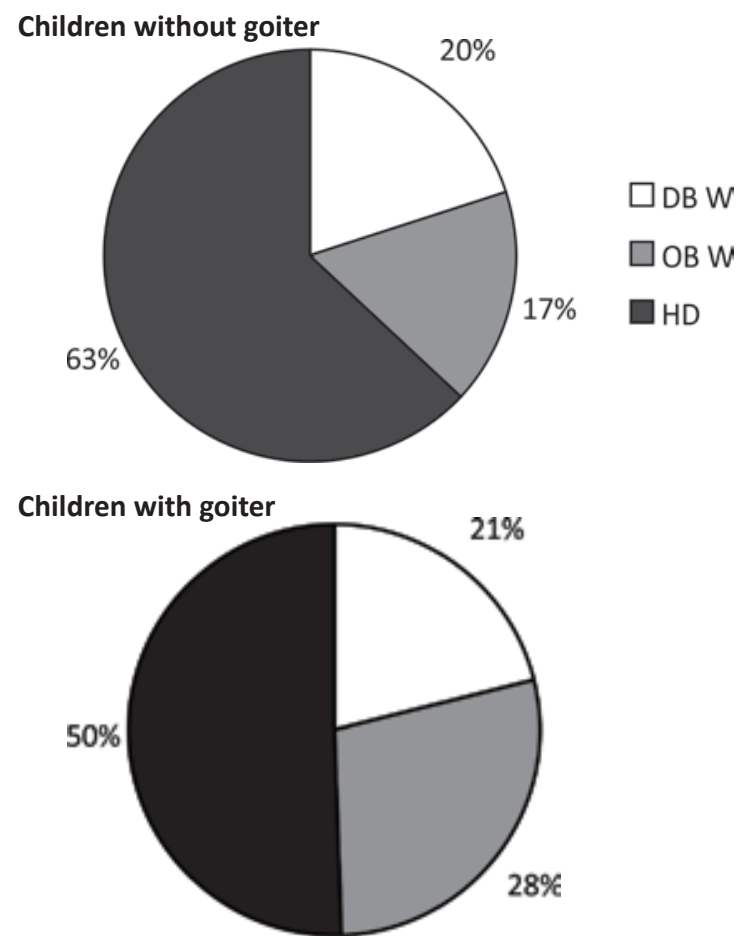

FIGURE 3. Indicators of children's physical development OBW - OVER BODY WEIGHT; DBW - DEFICIT BODY WEIGHT; HD - HARMONIOUS DEVELOPMENT
The results of the study showed that children mostly have an average degree of intellectual development $(58.9 \%)$. The level of intellectual formation changed in the direction of decreasing with increasing degree of iodine deficiency (Fig. 4). Thus, in children living in the plains the share of children with a high level of development ranged from 22.7 to $14.6 \%$, while in children from the mountainous zones -10.3 $-9.2 \%$ of people $(\mathrm{p}<0.05)$.

Children with high and medium level of intelligence development had sufficiently developed abstract forms of thinking, a large amount of knowledge. Children with a low level of intelligence were dominated by a primitive approach to solving logical problems, they were dominated by specific forms of thinking.

The results of the study of puberty with the assessment of the sexual development score of girls (SSDG) show (fig. 5) that girls living in the mountains have lower rates of sexual development. This difference is especially noticeable at the age of 13 . In other age groups there was a tendency to decrease $(\mathrm{p}>0.05)$.

Among girls from the mountain zone, II-III degree (SSDG lag of more than 3-4 years) of puberty delay (12.4 and 6.5\%) was more often registered than girls from the plain zone, where mostly I-II degree was observed(SSDG lag by 2-3 years) (34.7 and $13.8 \%$ ). All boys from the mountain zone have a tendency to delay sexual development (Table 6). A probable difference is observed in the group of 15-yearold boys $(\mathrm{p}<0.05)$.

\section{DISCUSSION}

The study found that the overall prevalence of goiter is high, especially in mountainous areas (59.8\%), which indicates that IDD is a serious health problem in Ukraine, despite the fact that in other regions of Ukraine the frequency of goiter among children is lower [30,31]. Iodine-deficient euthyroid goiter is the most common. This study found that iodine deficiency is more common in girls than in boys, which is consistent with other studies [32]. This can be explained by the greater need for iodine in girls, 


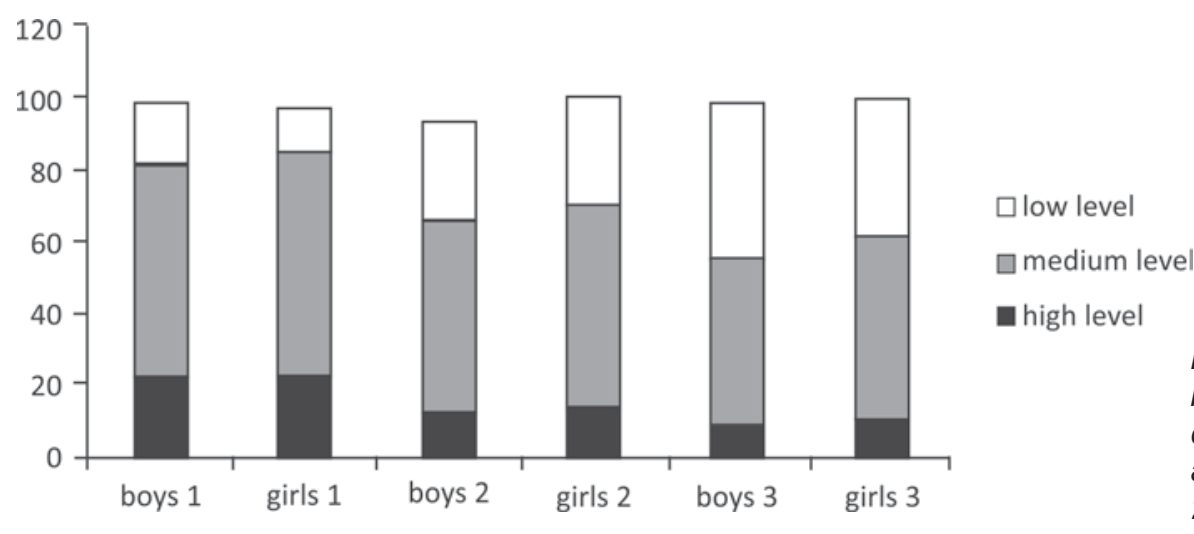

FIGURE 4. The level of formation of intellectual functions of school-age children depending on gender and area of residence (1 - Chernivtsi, 2 - Plain area, 3 - Mountain area)

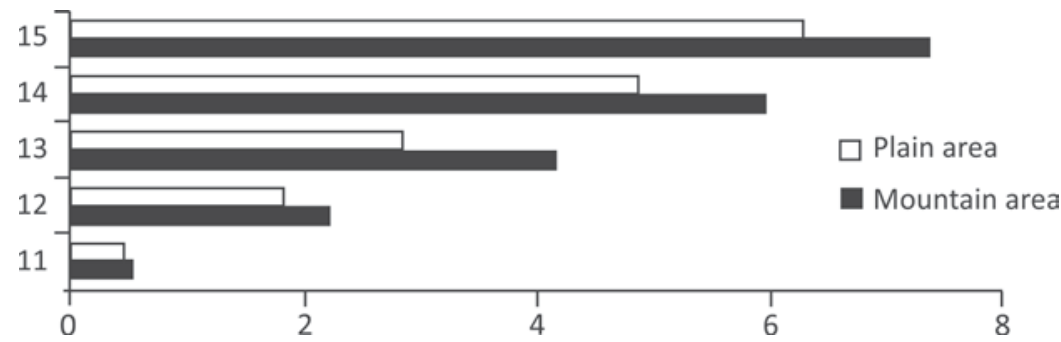

FIGURE 5. Average sexual development score of girls (SSDG) depending on the area of residence

TABLE 6. Indicators of sexual development of boys

\begin{tabular}{|c|c|c|c|c|c|}
\hline \multirow{2}{*}{$\begin{array}{c}\text { Age } \\
\text { (years) }\end{array}$} & \multirow{2}{*}{$\mathbf{n}$} & \multicolumn{2}{|c|}{ MI } & \multicolumn{2}{c|}{ Percentage } \\
\cline { 3 - 6 } & & Mountain area & Plain area & Mountain area & Plain area \\
\hline 11 & 23 & $2.21 \pm 0.11$ & $2.41 \pm 0.14$ & 42.8 & 48.4 \\
\hline 12 & 38 & $2.69 \pm 0.21$ & $2.89 \pm 0.27$ & 54.3 & 69.2 \\
\hline 13 & 30 & $3.12 \pm 0.11$ & $3.31 \pm 0.42$ & 62.3 & 78.5 \\
\hline 14 & 29 & $3.56 \pm 0.25$ & $3.72 \pm 0.89$ & 59.5 & $82.4^{*}$ \\
\hline 15 & 28 & $4.24 \pm 0.39$ & $5.91 \pm 0.32^{*}$ & 78.4 & $92.8^{*}$ \\
\hline
\end{tabular}

* - probably relative to the indicators of boys from the mountain zone $(p<0.05) ; \mathrm{MI}$-masculinization index

especially during puberty [33]. It is known that estrogen, which is a female hormone, has an inhibitory effect on the absorption of iodine by follicular cells of the thyroid gland. In addition, estrogen also increases the proliferation of thyroid follicles, which leads to an increase in the thyroid gland [34-36].

Urine iodine levels are used as a valuable indicator to measure the nutritional status of iodine and to assess IDD in humans, as $90 \%$ of iodine in the body is excreted with the urine [21]. Possible iodine deficiency is associated with low iodine content in soil, water, food [37,38], frequent consumption of digestible foods (cabbage, soybeans, turnips, millet, corn) [39-41] and insufficient levels of iodized salt [42]. In our study, the level of iodine in the urine ranged from 55 to $70 \mu \mathrm{g} / 1$, which meets the WHO criteria for mild iodine deficiency [43-44]. Similar results were obtained [45] - a slight deficiency of iodine in the urine in the age group of 7-10 years was in 58\% of children, at the age of 11-13 years - in 49\%. However, studies [46] showed that $84.2 \%$ of children have a level of ioduria greater than $100 \mu \mathrm{g} / \mathrm{l}$ and only $15.8 \%$ of ioduria corresponds to mild iodine deficiency, and studies [47] found high levels of ioduria. The possible reason for the higher prevalence of iodine deficiency goiter in this study may be due to several reasons: low iodine content in soil, water, and, accordingly, food (most children (68.4\%) lived in a mountainous iodine deficiency zone, respectively, they had the lowest median ioduria), low iodine content in food [48] (children mostly consume locally produced foods, iodized salt is partially consumed) and the consumption of digestible foods (including a large proportion of corn consumption). Thus, the rate of iodine depends on the climatogeographical zone of habitat, nutritional support [49] and the effectiveness of prevention of iodine deficiency [50-53]. Most studies confirm the negative impact of iodine deficiency on children [54], in particular, found a connection between iodine levels in the urine of a child and mental development, [55] identified the negative impact of iodine deficiency on physical and mental development [56], frequency of thyroid hyperplasia and goiter [57-60] showed the effect of iodine defi- 
ciency of the mother on fetus and newborn. In [6163] the researches results of Spain, Italy, Iran, Benin scientists on character of disturbances of neuropsychic development of children in areas were generalized and it is convincingly proved that in the conditions of iodine deficiency cognitive functions in children are essentially broken [64], and intellectual the coefficient (IQ-index) of the population of iodinedeficient regions is $10-15 \%$ lower than those in areas with adequate iodine consumption. In the work of Salarkia N. et al. [65] was demonstrated an increase in IQ from 89 to 97 points in rural children 7-13 years of age from the region of severe iodine deficiency 10 years after the introduction of combined iodine prophylaxis (injection of iodinated oil to mothers before conception or during pregnancy or children aged 1- 3 years, as well as eating only iodized salt). In addition, there was a decrease in the number of children with IQ below 70 points from $12 \%$ to 0 [64]. Aboud FE et al. [66] found the best Bailey scores in assessing the neuropsychological development of 1,835 infants aged 5-11 months before the families used iodized salt and the same children ( $85 \%$ of the sample) again after 20-29 months. Our study showed that children and adolescents living in iodine-deficient regions have significant abnormalities in physical development, especially in the presence of goiter. At the same time, there is a decrease in weight-height ratios, an increase in the proportion of children with body weight deficit, reduced body surface area, which confirms the results of our previous studies [67] and studies conducted by Kudabaeva HI et al. [68] and Turchina SI [69]. Surveys of more than 4 thousand children and adolescents of both sexes aged 8-17 years, conducted in the region of moderate iodine deficiency in Russia (Saratov region) showed that most morphological features (length, body weight, body mass index) in children with goiter had a significant lag from healthy peers $(\mathrm{p}<0.001)$. The authors associate such indicators with functional insufficiency of the thyroid gland [70]. Various reproductive disorders have been identified in children from the iodine deficiency region: high frequency of delayed puberty in boys and girls, later menarche, and ovarian-men- strual irregularities in adolescent girls [71]. In particular, a study by Heidari Z. et al [72] showed that one third of adolescent girls in the region of Shahriar, Iran, were iodine deficient (the incidence of mild, moderate and severe iodine deficiency was $22.4 \%$, $14.3 \%$ and $0 \%$, respectively).

This study found a high prevalence of respiratory diseases in children with iodine deficiency, including SARS, as well as digestive diseases. Other authors [73] established specific age peaks in the formation of chronic diseases in children in regions with iodine deficiency: at 3 years $(960.6 \%), 5$ years $(1,481 \%), 7$ years $(2,245.8 \%)$ and 12 years $(2,292.2 \%)$. Shilin $\mathrm{DE}$ [74] convincingly proved the formation of chronic somatic pathology from the first years of life and the presence of two or more diseases at the beginning of puberty in children with significant iodine deficiency in the diet [75]. Later, a number of authors have demonstrated in their work the connection of iodine deficiency with high morbidity of children of different ages, as well as infant mortality [76-78].

Our results also demonstrate the negative effects of iodine deficiency on children. IDD is an urgent task of health care in Ukraine. Continued monitoring of ioduria and children's health and the implementation of health measures at the national, regional and individual levels, including public nutrition education programs, are needed.

\section{CONCLUSIONS}

The results of our study showed that with some external well-being, children from the iodine deficiency region are characterized by abnormalities in health (goiter frequency, disharmony of physical development, borderline cognitive disorders, impaired rate and timing of puberty), which differ depending on the degree of iodine deficiency. Since the examined children were standardized according to the main factors of influence, it can be assumed that the detected changes are provoked mainly by iodine deficiency in the environment. Future complications can be prevented by using a method of testing iodine in the urine and studies of thyroid hormone levels.

\section{REFERENCES}

1. WHO/ICCIDD/UNICEF. Assessment of iodine deficiency disorders and monitoring their elimination. 2nd Edition. Geneva: WHO, 2001.

2. Biban BG, Lichiardopol C. lodine Deficiency, Still a Global Problem?. Curr Health Sci J. 2017;43(2):103-111.

3. FAO/WHO/IAEA Expert Consultation. Trace Elements in Human Nutrition and Health. 1996.

4. A Cesar J, S Santos I, E Black R, Chrestani MAD, Duarte FA, Nilson EAF. Iodine Status of Brazilian School-Age Children: A National Cross-Sectional Survey. Nutrients. 2020;12(4):1077.

5. Panth P, Guerin G, DiMarco NM. A Review of lodine Status of Women of Reproductive Age in the USA. Biol Trace Elem Res. 2019;188(1):208-220.

6. Khattak RM, Ittermann T, Nauck M, Below H, Völzke H. Monitoring the prevalence of thyroid disorders in the adult population of Northeast Germany. Popul Health Metr. 2016;14:39.

7. Henjum S, Aakre I, Lilleengen AM et al. Suboptimal lodine Status among Pregnant Women in the Oslo Area, Norway. Nutrients. 2018;10(3):280 
8. Sun D, Codling K, Chang S et al. Eliminating lodine Deficiency in China: Achievements, Challenges and Global Implications. Nutrients. 2017;9(4):361.

9. Lou X, Wang X, Mao G et al. Geographical influences on the iodine status in pregnant women, neonates, and school-age children in China. Nutr J. 2020;19(1):7.

10. Ahn J, Lee JH, Lee J, et al. Association between urinary sodium levels and iodine status in Korea. Korean $\mathrm{J}$ Intern Med. 2020;35(2):392-399.

11. Çelmeli G, Çürek Y, Özen Küçükçetin İ et al. The Results of 16 Years of lodization: Assessment of lodine Deficiency Among School-age Children in Antalya, Turkey. J Clin Res Pediatr Endocrinol. 2020;12(3):256-260.

12. Singh A, Purani C, Mandal A, Mehariya KM, Das RR. Prevalence of Thyroid Disorders in Children at a Tertiary Care Hospital in Western India. J Clin Diagn Res. 2016;10(2):SC01-SC4.

13. Khattak RM, Khattak MNK, Ittermann T, Völzke H. Factors affecting sustainable iodine deficiency elimination in Pakistan: A global perspective. J Epidemiol. 2017;27(6):249-257.

14. Workie SB, Abebe YG, Gelaye AA, Mekonen TC. Assessing the status of iodine deficiency disorder (IDD) and associated factors in Wolaita and Dawro Zones School Adolescents, southern Ethiopia. BMC Res Notes. 2017;10(1):156.

15. Zygmunt A, Adamczewski Z, Wojciechowska-Durczynska K, et al. Evaluation of the effectiveness of iodine prophylaxis in Poland based on over 20 years of observations of iodine supply in school-aged children in the central region of the country. Arch Med Sci. 2019;15(6):1468-1474.

16. Korobitsyna R, Aksenov A, Sorokina T, et al. lodine Status of Women and Infants in Russia: A Systematic Review. Int J Environ Res Public Health. 2020;17(22):8346.

17. Hatch M, Polyanskaya O, McConnell R, et al. Urinary lodine and Goiter Prevalence in Belarus: experience of the Belarus-American cohort study of thyroid cancer and other thyroid diseases following the Chornobyl nuclear accident. Thyroid. 2011;21(4):429-437.

18. D’Elia L, Obreja G, Ciobanu A, Breda J, Jewell J, Cappuccio FP. Sodium, Potassium and lodine Intake, in A National Adult Population Sample of the Republic of Moldova. Nutrients. 2019;11(12):2896.

19. Dunn JT. lodine deficiency disorders. UpToDate, www.uptodate.com 1998.

20. Hetzel BS. The nature and magnitude of the iodine deficiency disorders (IDD). In: Hetzel BS, Delange F, Dunn J, Ling Jack, Mannar V, Pandav Ch, editors. Towards the Global Elimination of Brain Damage Due to lodine Deficiency. New Delhi: Oxford University Press; 2004:10-20.

21. WHO. In: Assessment of iodine deficiency disorders and monitoring their elimination: a guide for programme managers. Third, editor. Geneva: World Health Organization; 2007.

22. de Benoist B, McLean E, Andersson M, Rogers L. lodine deficiency in 2007: global progress since 2003. Food Nutr Bull. 2008; 29(3): 195-202.

23. WHO . The WHO vitamin and mineral nutrition information system (VMNIS) on iodine deficiency disorders. Geneva: World Health Organization; 2009.

24. Henjum S, Aakre I, Lilleengen AM et al. Suboptimal lodine Status among Pregnant Women in the Oslo Area, Norway. Nutrients. 2018;10(3):280.

25. Nechitaylo YM. Anthropometric standards in children. Chernivtsi: BSMA Publishing House.1999:144 p.

26. Aleksandrovskaya EM, Gilyasheva IN. An adapted modified version of the children's personal questionnaire by R. Kettel (Methodical recommendations); 1985.

27. Guidelines for Clinical Endocrinology. Ed. Starkova NT. 1996.

28. WHO classification of goiter. (World Health Organization, United Nation Children's Fund, International Council for Control of lodine Deficiency Disorders. Assessment of the iodine deficiency disorders and monitoring their elimination. Geneva: World Health Organization; 2001. WHO document WHO/NHD/01.1.

29. Zimmermann MB, Hess SY, Molinari L et al. New reference values for thyroid volume by ultrasound in iodine-sufficient schoolchildren: a
World Health Organization/Nutrition for Health and Development Iodine Deficiency Study Group Report. American Journal of Clinical Nutrition 2004;79:231-237.

30. Tymchenko AM, Misyura KV. Dynamics of distribution of thyroid pathology among the population in regions with various degrees of iodine deficit and directions of prevention. International Journal of Endocrinology 2007;3(9):75-77.

31. Luzanchuk IA, Kravchenko VI, Turchin VI. Goiter endemic among children of Kharkiv, Dnipropetrovsk, Donetsk regions and the Autonomous Republic of Crimea. Endocrinology. 2004;9 (1): 46-52.

32. Mezgebu Y, Mossie A, Rajesh PN, Beyene G. Prevalence and Severity of lodine Deficiency Disorder Among Children 6-12 Years of Age in Shebe Senbo District, Jimma Zone, Southwest Ethiopia. Ethiopian Journal of Health Sciences 22(3):196-204

33. Nussey S, Whitehead S. The Thyroid Gland. Endocrinology: An Integrated Approach. BIOS Scientific Publishers. 2001.

34. Furlanetto TW, Nunes Jr RB, Sopelsa AMI, Maciel RMB. Estradiol decreases iodide uptake by rat thyroid follicular FRTL-5 cells. Braz J Med Biol Res, 2001; 34(2): 259-263.

35. Berg V, Nøst TH, Skeie G, et al. Thyroid homeostasis in mother-child pairs in relation to maternal iodine status: the MISA study. Eur J Clin Nutr. 2017;71(8):1002-1007.

36. Kapelari K, Kirchlechner C, Hogler W, Schweitzer K, Virgolini I, Moncayo R. Pediatric reference intervals for thyroid hormone levels from birth to adulthood: a retrospective study. BMC Endocr Disord 2008; 8: 15.

37. Carriquiry AL, Spungen JH, Murphy SP et al. Variation in the iodine concentrations of foods: considerations for dietary assessment. Am J Clin Nutr. 2016;104(3):877-887.

38. Sun DJ, Codling K, Chang SY et al. Eliminating iodine deficiency in China: Achievements, challenges and global implications. Nutrients. 2017:9:361.

39. Dessie G, Amare D, Dagnew AB et al. Prevalence of goiter among children in Ethiopia and associated factors: a systematic review and meta-analysis. BMC Public Health. 2019;19(1):1191.

40. Lee KW, Shin D, Cho MS, Song WO. Food Group Intakes as Determinants of lodine Status among US Adult Population. Nutrients. 2016;8(6):325.

41. Amar KC, Sanjukta M, Dishari L \& Smritiratan T. Goitrogenic content of Indian cyanogenic plant foods \& their in vitro anti-thyroidal activity. Indian J Med Res. 2004;119:180-185.

42. Wang X, Lou X, Mo Z et al. Poor lodine Knowledge, Coastal Region, and Non-lodized Salt Consumption Linked to Low Urinary lodine Excretion in Zhejiang Pregnant Women. Nutrients. 2019;11(2):413.

43. WHO, UNICEF, ICCIDD. lodine deficiency in Europe: a continuing public health problem. Geneva: World Health Organization, 2007;8-39.

44. Zimmermann MB. Symposium on 'Geographical and geological influences on nutrition'. lodine deficiency in industrialised countries. Proceedings of the Nutrition Society. 2010;69:133-143.

45. Tapeshkina NV, Lobykina EN, Zinchuk SF. Assessment of iodine security in Mezhdurechensk and the state of prevention of iodine deficiency. J Medicine and Education in Siberia. 2013;6:68:70.

46. Stepanova E, Morugova T, Denisova S. loduria as a criterion for iodine deficiency. Abstracts of the VII Russian Congress of Endocrinologists. UP Print, 2016.

47. Yablonskaya IV, Zhavoronok SV, Stozharov AN. The level and structure of thyroid pathology in the Gomel region are typical for regions with an iodine surplus in the diet of the population. Medical Journal. 2020;3:120-125.

48. Rohner F, Zimmermann M, Jooste P, Pandav C, Caldwell K, Raghavan R, Raiten DJ. Biomarkers of nutrition for development iodine review. J Nutr. 2014 Aug;144(8):1322S-1342S.

49. Roman VB, Ribas BL, Ngo J, Gurinovic M, Novakovic R, Cavelaars A et al. Projected prevalence of inadequate nutrient intakes in Europe. Ann Nutr Metab. 2011;59:84-95.

50. Gerasimov G.A. On the new WHO and UNICEF recommendations for the prevention of iodine deficiency diseases. Wedge. and expert. thyroidol. 2008;4(1):2-7.

51. Abdulhabirova F.M. Prevention of iodine deficiency diseases in children. Cons. Med. Pediatrics (Suppl.) 2010;4:88-92. 
52. Angermayr L, Clar C. WITHDRAWN: Iodine supplementation for preventing iodine deficiency disorders in children. Cochrane Database Syst Rev. 2018;11(11):CD003819.

53. Farebrother J, Naude CE, Nicol L, Sang Z, Yang Z, Jooste PL, Andersson M, Zimmermann MB. Effects of lodized Salt and lodine Supplements on Prenatal and Postnatal Growth: A Systematic Review. Adv Nutr. 2018 May 1;9(3):219-237.

54. Yuksek SK, Aycan Z, Oner O. Evaluation of lodine Deficiency in Children with Attention Deficit/Hyperactivity Disorder. J Clin Res Pediatr Endocrinol. 2016;8(1):61-66.

55. Bougma K, Aboud FE, Harding KB, Marquis GS. lodine and mental development of children 5 years old and under: a systematic review and meta-analysis. Nutrients. 2013;5(4):1384-1416.

56. Vermiglio F, Lo Presti VP, Moleti M, Sidoti M, Tortorella G, Scaffidi G et al. Attention deficit and hyperactivity disorders in the offspring of mothers exposed to mild-moderate iodine deficiency: a possible novel iodine deficiency disorder in developed countries. J Clin Endocrinol Metab. 2004; 89: 6054-6060.

57. Xiu L, Zhong G, Ma X. Urinary iodine concentration (UIC) could be a promising biomarker for predicting goiter among school-age children: A systematic review and meta-analysis. PLoS One. 2017 Mar 22;12(3): 0174095.

58. Manousou S, Stål M, Eggertsen R, Hoppe M, Hulthén L, Filipsson Nyström $\mathrm{H}$. Correlations of water iodine concentration to earlier goitre frequency in Sweden-an iodine sufficient country with long-term iodination of table salt. Environ Health Prev Med. 2019;24(1):73.

59. Zimmermann MB, Gizak M, Abbott K, Andersson M, Lazarus JH. lodine deficiency in pregnant women in Europe. Lancet Diabetes Endocrinol. 2015;3:672-674.

60. Andersen SL, Laurberg P. lodine Supplementation in Pregnancy and the Dilemma of Ambiguous Recommendations. Eur Thyroid J. 2016;5(1):35-43.

61. Delange F. lodine deficiency as a cause of brain damage. Postgrad Med J. 2001;77:217-20.

62. Delange F. Optimal iodine nutrition during pregnancy, lactation and the neonatal period. Int J Endocrinol Metab 2004;2:1-12.

63. Godina EZ, Zadorozhnaya LV, Khomyakova IA et al. Features of the somatic development of children and adolescents in conditions of iodine deficiency (based on the survey of the population of the Saratov region). Physiology of growth and development of children and adolescents. T. 1. Ed. Baranova AA, Scheplyagina LA. M.: GEOTAR-Media, 2006:181-231.

64. Bougma K, Aboud FE, Harding KB, Marquis GS. lodine and mental development of children 5 years old and under: a systematic review and meta-analysis [published correction appears in Nutrients]. Nutrients. 2014;6(12):5770-5771.

Conflict of interest: none declared Financial support: none declared
65. Salarkia N, Mirmiran P, Azizi F. Timing of the effect of iodine supplementation on intelligence quotients of schoolchildren. Int $\mathrm{J}$ Endocrinol Metab 2004;2:95-102.

66. Aboud FE, Lemma TM, EA, Marquis GS. Introduction of iodised salt benefits infants' mental development in a community-based cluster-randomised effectiveness trial in Ethiopia. $\mathrm{Br} J$ Nutr. 2018;119(7):801-809.

67. Sorokman TV. Indicators of development of a childish lifestyle, as they live in the minds of iodine deficiency. Health of the child. 2015;2 (61):40-44.

68. Kudabaeva HI, Nuftieva Al, KoshmaganbetovA GK, Bazargaliev ES. Physical development of prepubertal children with an enlarged thyroid gland in the Aktobe region. Bulletin of the Kazakh National Medical University 2015;1:45-48.

69. Turchina SI. Complex approach to correction of somatostatic development of children and children with diffuse non-toxic goiter. Modern Pediatrics. 2014;5 (61):97-102.

70. Godina EZ, Khomyakova IA, Purundjan AL, Zadorozhnaya LV, Stepanova AV. Some trends in the somatic development of children and adolescents under iodine-deficiency: materials from the Saratov region. J Physiol Anthropol Appl Human Sci. 2005;24(4):313-319.

71. Gurska, VA. Particularities of parameters in physical and state development in case of breakdown of puberty among boys for minds of iodine deficiency. Problems of endocrine pathology. 2007;1:47-49.

72. Heidari Z, Arefhosseini SR, Hedayati M, Vaghef-Mehrabany E, Ebrahimi-Mameghani M. lodine status, and knowledge about iodine deficiency disorders in adolescent school girls aged 14-19 years, 2016. Health Promot Perspect. 2019;9(1):77-84.

73. Godina EZ, Khomyakova IA, Zadorozhnaya LV Secular changes in body dimensions and sexual maturation in children of Arkhangelsk city. Anthropol Anz. 2016;73(1):45-59.

74. Shilin DE. The role of iodine prophylaxis in the complex rehabilitation of frequently ill children. Doctor. 2007;10:8-13.

75. Naumova YuV, Kurmacheva NA, Rogozhina IE. The health status of pregnant women and newborns, depending on the quality of iodine prophylaxis. Saratov J Med Sci Res. 2010;6 (3):535-40.

76. Troshina EA, Abdulhabirova FM, Skrynnik EN. Prevention of diseases associated with iodine deficiency in groups at high risk of their development. Cons Med Women Health. 2010;12(6):17-20.

77. Nyström HF, Brantsæter AL, Erlund I et al. lodine status in the Nordic countries - past and present. Food Nutr Res. 2016;60:31969.

78. GBD 2016 Disease and Injury Incidence and Prevalence Collaborators. Global, regional, and national incidence, prevalence, and years lived with disability for 328 diseases and injuries for 195 countries, 1990-2016: a systematic analysis for the Global Burden of Disease Study 2016. Lancet. 2017;390(10100):1211-1259. 